\title{
Clinical and Radiographic Evaluation of Chloramphenicol-Tetracycline-Zinc Eugenol Oxide Antibiotic Paste in Pulp Treatment
}

(Penilaian Klinikal dan Radiografik Pes Antibiotik Kloramfenikol-Tetrasiklin-Zink Eugenol Oksida dalam Rawatan Pulpa)

\author{
JESÚs LUENGO FEREIRA*, HERACLIO REYES RIVAS, IOVANNA TOSCANO, \\ LuZ ElENA CARlos MEDRANO \& Minerva ANAYA AlVAREZ
}

\begin{abstract}
This study has been carried out to evaluate the clinical and radiographic CTZ (Chloramphenicol-Tetracycline-Zinc Eugenol Oxide) antibiotic paste in pulpotomies of primary molars. A Quasi-experimental study in 43 primary molars of children aged 3 to 7 years. Pulpotomies were performed on the selected patients with the CTZ antibiotic paste. Teeth were restored with glass ionomer and preformed steel metal crowns. Clinical and radiographic evaluation was performed at 6 and 12 months. SPSS V-19 program for data analysis and chi-square test was used up to 5\%. Success rates were observed during the evaluation periods of time. $93 \%\left(x^{2}=0.446, \mathrm{p}>0.05\right)$ and $88.4 \%\left(x^{2}=0.431, \mathrm{p}>0.05\right)$ of the clinical form; $97.7 \%\left(x^{2}=0.534, \mathrm{p}>0.05\right)$ and $93 \%\left(x^{2}=0.553, \mathrm{p}>0.05\right)$ were radiographic, at 6 and 12 months, respectively. The CTZ antibiotic paste is an alternative in the treatment of pulpotomy of molars. It provides an antimicrobial effect, decreased operative time, without causing trauma to the pediatric patient.
\end{abstract}

Keywords: Antibiotic paste; CTZ; primary molars; pulpotomy

\section{ABSTRAK}

Kajian ini telah dijalankan bagi penilaian klinikal dan radiografik pes antibiotik CTZ (Kloramfenikol-Tetrasiklin-Zink Eugenol Oksida) dalam pulpotomi pada geraham primer. Kajian eksperimen-Quasi dijalankan pada 43 geraham primer ke atas kanak-kanak berumur 3 hingga 7 tahun. Pulpotomi dilakukan pada pesakit terpilih dengan pes antibiotik CTZ. Gigi telah dipulihkan dengan glass ionomer dan pra-bentuk besi keluli korona. Penilaian klinikal dan radiografik dilakukan pada 6 dan 12 bulan. Program SPSS V-19 bagi analisis data dan ujian khi kuasa dua digunakan sehingga 5\%. Kadar kejayaan diperhatikan semasa tempoh penilaian masa. 93\% $\left(x^{2}=0.446, \mathrm{p}>0.05\right)$ dan $88.4 \%\left(x^{2}=0.431, \mathrm{p}>0.05\right)$ adalah bentuk klinikal; $97.7 \%\left(x^{2}=0.534, \mathrm{p}>0.05\right)$ dan 93\% ( $\left.x^{2}=0.553, \mathrm{p}>0.05\right)$ adalah radiografik, pada 6 dan 12 bulan. Pes antibiotik CTZ adalah alternatif bagi rawatan molar pulpotomi. Ia memberikan kesan antimikrobial dan memendekkan masa operasi tanpa menyebabkan trauma kepada pesakit pediatrik.

Kata kunci: CTZ; geraham primer; pes antibiotik; pulpotomi

\section{INTRODUCTION}

Dental decay prevalence in the primary dentition continues to maintain high levels in the infant population, despite the efforts and advances that have been made in the field of oral health prevention programs (Molina et al. 2015). This situation increases the possibilities of pulp involvement due to the presence of deep caries, leading pulp to an irreversible state, implying the need to perform a pulp treatment (Acevedo et al. 2009; Passos et al. 2008).

There are different techniques and protocols for the treatment of the pulp in primary teeth, reliant on the extent of the damage and the pathological compromise (Pimienta et al.2015; Simancas et al. 2010). Pulpotomy is the main therapeutic alternative indicated for the treatment of primary teeth with reversible coronal inflammation and pulp vitality, when there is no involvement of the root pulp or signs and symptoms of pulpal degeneration (Gonzalez et al. 2016). This procedure is based on the fact that after surgical amputation of the infected coronal pulp, the root pulp tissue remains on a healthy state, supporting the existence of a natural environment for the normal development of the successor tooth (Liu et al.2011; Yildirim et al. 2016).

The characteristics for a more suitable material for pulp treatment, has to have specific physical and biological features, such as a good seal in the remnant pulp tissue, also it has to be lack of absorption, biocompatible and not less important the antibacterial property. All these features become very important because of the necessity to avoid mistakes due the endodontic treatment and also the possibility of inflammatory and infectious processes among the radicular conduct (Oliveira et al. 2013).

Therefore, the complex anatomy of primary teeth, coupled with the range of materials and currently available drugs for pulp treatment and the difficulty of clinicians to perform a correct diagnosis, preferred the use of antibiotic 
pastes as an alternative within endodontic therapy, mainly due to its antimicrobial capacity, decrease in costs and faster application (Subramaniam \& Gilhotra 2011).

According to these, the development and uses of the pulpotomy technique through antibiotic pastes used in primary dental organs with pulp involvement and/or doubtful prognosis has been booming in Latin America as an alternative for pulp treatment of temporal molars (Daher et al. 2015; Luengo et al. 2016; Mariz et al. 2014). CTZ paste was described in 1959 by Sollier \& Cappiello, for the treatment of temporal molars with pulp involvement (Mariz et al. 2014; Passos et al. 2008; Perona \& Mungi 2014). In its composition is Chloranfenicol $500 \mathrm{mg}$, Tetracycline 500 $\mathrm{mg}$, Zinc Oxide $1000 \mathrm{mg}$ and Eugenol (1 drop) (Perona \& Mungi 2014); being the last two added during the operative act (Daher et al. 2015).

There are studies that indicate the effectiveness of CTZ antibiotic paste was due to its antimicrobial action, mainly due to the presence in its composition of two broad spectrum antibiotics: tetracycline and chloramphenicol (Luengo et al. 2016; Reis et al. 2016; Siegl et al. 2015). The first drug is an antimicrobial that acts against a large number of aerobic bacteria, facultative anaerobes and spirochetes, as well as Gram (+) and Gram (-) microorganisms. The second drug is a broad-spectrum antibiotic, which can be bactericidal at high concentrations, offers excellent effectiveness against Gram (-) bacteria and against all anaerobes; due to its great solubility allow a wide distribution by the tissues and body fluids, increasing its power of action. The Zinc oxide-eugenol, provides analgesic properties and a potent antibacterial action against Staphylococcus, Micrococci, Bacillus and Enterobacteria for more than 30 days (Reis et al. 2016).

The CTZ paste (Chloramphenicol, Tetracycline, Zinc Oxide Eugenol) application technique is easy, simple, can be performed in one session, has antibacterial power, promotes stabilization of bone resorption and does not cause tissue sensitivity (Luengo et al. 2016; Mariz et al. 2014). Additionally, it does not require root canal instrumentation, regardless of pulpal diagnosis (Oliveira \& Costa 2006), this offers a great advantage in the treatment of non-cooperative patients, facilitating the management of pediatric patient behavior (Pinky et al. 2011), reducing operative time (Luengo et al. 2016; Mariz et al. 2014). However, at the moment of being employed, the pigmentation of the crown of the treated tooth must be taken into account (as a possible disadvantage) (Silva \& Leache 2010).

Despite the known clinical success of the conventional endodontic technique with formocresol and through the use of other materials, the evidence on the use of antibiotic paste in the treatment of pulpotomies of primary pulp vitality is limited today; there is a need to develop clinical studies in order to verify the clinical and radiographic results of the primary teeth treated under this approach. The purpose of the present study was to evaluate clinically and radiographically the effectiveness of CTZ antibiotic paste (Chloramphenicol, Tetracycline, Zinc Oxide Eugenol) in the treatment of vital pulpotomies in primary molars.

\section{MATERIALS AND METHODS}

\section{STUDY POPULATION}

The study was approved by the Bioethics Committee of the Health Sciences Area of the Autonomous University of Zacatecas (document 038/2015). Forty three children were considered for this study, both sexes, between 3 and 7 years old, who attended the Pediatric Dentistry Clinic of the Autonomous University of Zacatecas during the period of January-July 2015.

Also, patients with clinical signs of deep decay in temporary molars in vital pulps were considered for the study, without previous treatment, radiographic evidence of root length greater than half $(60 \%)$ and without images of pathological signs, exposure and bleeding of the normallooking pulp chamber, with an intense red coloration, with a control time of haemorrhage not greater than $5 \mathrm{~min}$ (with the use of physiological serum). Only then the pulp tissue in the root canals was assumed to be normal.

Patients with clinical and/or radiographic signs and symptoms of pulp or radicular deterioration were excluded; spontaneous pain or at palpation, heat changes or even chewing; with an inflammation sign, edema, redness, heat, redness, localized abscess, fistulous button, pulp chamber with foul odor and/or purulent exudate, pathological mobility, cellulitis, dark-thick bleeding. Radiographically: Radiolucent image on periapical and / or interradicular region, internal or external dentin resorption, radiolucent in furca area; patients with systemic diseases and noncollaborators, also were excluded from the study.

Legal representative received a detailed report and signed a consent form to authorize his participation in the study, in accordance with the principles of the Helsinki Declaration (World Medical Association 2013).

\section{EXPERIMENTAL DESIGN}

A quasi-experimental study was carried out, using nonprobabilistic sampling for convenience. Designated patients who fulfill the inclusion criteria were assigned

TABLE 1. Distribution of participants according to age and gender

\begin{tabular}{llccc}
\hline & & \multicolumn{2}{c}{ Gender } \\
\cline { 3 - 5 } Age & & General & Female & Male \\
\cline { 3 - 5 } & Media & 4.55 & 4.4211 & 4.6667 \\
& Standard deviation & 0.959 & 1.01739 & 0.91287 \\
\hline
\end{tabular}


to apply the antibiotic paste CTZ (Chloramphenicol, Tetracycline, Zinc Oxide Eugenol, $n=43$ ).

\section{CLINICAL PROCEDURES}

A trained dentist performed all pulpotomies in a single session, using CTZ (powdered formula with $500 \mathrm{mg}$ Tetracycline, $500 \mathrm{mg}$ Chloramphenicol and ZOE, mixed with eugenol in a 1:1:2 ratio), under absolute isolation, infiltrative or troncomandibular anesthesia protocol according to the case (scandonest 2\%). Material (paste) manipulation was performed by another trained dentist.

Pulp chamber access and decay tissue was removed from the cavity with high speed and sterilized round \#5 carbide burs. Subsequently, the coronary pulp was removed with \#17 and \#18 Hu-Frieddy ${ }^{\circledR}$ sterilized dentin excavators and also it was perform an additional dental wear with Endo-Z® (Dentsply USA) bur. Bleeding caused during the operation was controlled by irrigation with physiological serum, using $10 \mathrm{~mL}$ disposable syringes and applying pressure with sterile cotton swabs.

\section{TECHNIQUE WITH ANTIBIOTIC PASTE (CTZ)}

CTZ antibiotic paste (Chloramphenicol, Tetracycline, Zinc Oxide Eugenol) manipulation was performed following the instructions in the literature (Havale et al. 2013). After removal of the complete cameral pulp and stop bleeding, the CTZ antibiotic paste was filled in the bottom of the pulp chamber/floor (approximately $2 \mathrm{~mm}$ thick), IRM ${ }^{\circledR}$ cement (Dentsply-USA) was then placed and sealed with glass ionomer (Ketac Molar® 3M ESPE). Fifteen days after treatment procedures, all patients were observed to confirm the absence of pathological clinical signs. Then, stainless steel crowns (3M Dental Products $®)$ were cemented with glass ionomer (Ketac ${ }^{\circledR}, 3 \mathrm{M}$ ESPE AG) and placed on molars. Dental occlusion was verified and adjusted.

\section{EVALUATION}

Clinical and radiographically evaluations were performed at 6 and 12 months, by a pediatric dentist who did not interfere in the execution of the procedures.

As a clinical success, the absence of any abnormal condition was considered; while on the other hand, as failure treatment was consider to have at least one of the following: pain, inflammation, absence of fistula, fistula scarring, abscess, purulent exudate, fetid odor, cellulitis, pathological dental movement, the condition of periodontal tissues and other condition not described above; and

Radiographic success was considered by the absence of images which indicated the presence of any condition outside the normal; and failure as the existence of: periodontal and / or periapical abscess, furca injury, bone trabeculae loss, external or internal root resorption, irregular thickening of the periodontal ligament, or any other condition, not included in the previous ones, observed by the evaluator.

\section{STATISTICAL ANALYSIS}

Statistical processing was performed using the SPSSWindows V-19.0 application (SPSS, INC, Chicago IL) software. Percentages and frequencies were calculated through descriptive variables such as gender, clinical and radiographic success. Means and standard deviation were obtained for quantitative variables such as age. For the comparative analysis, Chi square test was used at a significance level of $5 \%$.

\section{RESULTS}

After 12 months of evaluation, all the patients concluded the study, being distributed in $20(46.6 \%)$ of the female sex and $23(53.4 \%)$ of the male sex, showing a mean age of $4.55 \pm 0.95$ (Table 1).

\section{CLINICAL EVALUATION}

Six months evaluation showed a high clinical behavior of the CTZ antibiotic paste (93\%), having only 3 cases of failure $(7 \%)$ in molars presenting gingiva redness $\left(\mathrm{x}^{2}\right.$ $=0.446, p>0.05)$. A similar case was observed after 12 months of evaluation, where treatment reached $88.4 \%$ success, finding $11.6 \%$ of failures, 4 molars with gingiva redness and 1 with fistula scarring $\left(\mathrm{x}^{2}=0.431, p>0.05\right.$ (Table 2).

\section{RADIOGRAPHIC EVALUATION}

Only 1 molar (2.3\%) showed irregular thickening of the periodontal ligament after 6 months of evaluation,

TABLE 2. Clinical assessment according to gender

\begin{tabular}{|c|c|c|c|c|c|c|}
\hline \multirow{2}{*}{ Gender } & \multicolumn{6}{|c|}{ Clinical Evaluation } \\
\hline & \multicolumn{3}{|c|}{6 months } & \multicolumn{3}{|c|}{12 months } \\
\hline & Success & Failure & $\mathrm{p}^{*}$ & Success & Failure & $\mathrm{p}^{*}$ \\
\hline & $\mathrm{n}(\%)$ & $\mathrm{n}(\%)$ & & $\mathrm{n}(\%)$ & $\mathrm{n}(\%)$ & \\
\hline Female $(n=20)$ & $18(90.0)$ & $2(10.0)$ & & $17(85.0)$ & $3(15.0)$ & \\
\hline Male $(n=23)$ & $22(95.7)$ & $1(4.3)$ & 0.446 & $21(91.3)$ & $2(8.7)$ & 0.431 \\
\hline Total $(n=43)$ & $40(93.0)$ & $3(7.0)$ & & $38(88.4)$ & $5(11.6)$ & \\
\hline
\end{tabular}

* Chi Square Test 
representing a radiographic success rate of almost all $(97.7 \%)$ of the sample $\left(x^{2}=0.534, p>0.05\right)$, this fact happened on a similar way in the 12 months evaluation where there was a low failure rate $(7 \%)$ with 2 cases of irregular thickening of the periodontal ligament and 1 with radiolucent image on furca area $\left(\mathrm{x}^{2}=0.553, p>0.05\right.$ (Table 3).

\section{DISCUSSION}

Dental decay is one of the most common pathologies affecting the oral health of children. When comparing the structure of primary teeth with permanent teeth, the enamel and dentin are thinner, the enamel is more porous, the dental tubules are wider and also the pulp chamber is wider. In addition, the inadequate maintenance of oral hygiene and the consumption of sugars often lead to a faster spread of caries and an early involvement of the pulp in the primary teeth compared to permanent teeth, there for the conventional treatment is a pulpotomy (Alolofi et al. 2016).

Pulpotomy is considered a conservative treatment to reverse the inflammatory process of the pulp, limiting itself only to its removal inside the pulp chamber, with the objective of preserving radicular pulp, maintaining pulp vitality and eventually to the tooth (Bruno et al. 2006). However, in situations on which the pathological process of dental caries progresses rapidly, the degeneration of the pulp may evolve producing abscesses and necrosis and in many cases the pulpectomy is recommended. Nonetheless, deciduous teeth should be considered to have different tissue structures and reactions than permanent teeth, which sort some forms of treatment less suitable. Also, when studying the anatomy of the primary teeth, it is observed that they present complex, irregular, narrow root canals and accessory ducts, which makes it difficult to correctly manipulate them when performing pulp procedures such as pulpectomy (Hoelscher et al. 2006).

Encountered with this situation, the use of antibacterial drugs to treat endodontic injuries is one of the clinical procedures that can be used. However, it has been reported that when a systemic antibiotic is administered, only a small part of the drug concentration reaches the root canal, which makes it of little benefit. In view of the above, the application of local antibiotics allows to administer substantially higher concentrations and to avoid systemic complications (Nanda et al. 2014). This evidence has allowed for several years in the Pediatric Dentistry Specialty Clinic from the Autonomous University of Zacatecas to establish a non-instrumented endodontic treatment in primary teeth by using an antibiotic paste containing the antibacterial drug mixture for the treatment of dental organs with pulp involvement and doubtful prognosis. This biological approach is considered innovative because mechanical instrumentation is not required, which avoids further root canal expansion, unnecessary irritation on periapical tissues, decreasing operative times (performed in a single appointment) and can be applied satisfactorily in young children during early childhood (Luengo et al. 2016; Takushige et al. 2008).

This study evaluated clinical and radiographic treatments of pulpotomies performed with the antibiotic paste CTZ (Chloramphenicol, Tetracycline, Zinc Oxide Eugenol) during a period of 6 and 12 months in a group of children between 3 and 7 years old. During the evaluations, our results did not show statistically significant differences in success rates and failure rates. However, it was possible to observe a clinical and radiographic efficiency above $85 \%$ in both evaluation periods.

The results showed similarity with previous studies performed by Takushige et al. (2009) who observed a good clinical evolution of $95 \%$ in molars treated with the non-instrumented technique and with the application of an antibiotic paste. Likewise, they agree with Nakornchai et al. (2010) who reported $100 \%$ clinical success and $76 \%$ radiographic success and with Luengo et al. (2016) who found $80 \%$ clinical and radiographic success. However, they differ slightly from the clinical point of view of the values reported by Trairatvorakul and Detsomboonrat (2012), which show $75 \%$ of clinical success and low radiographic success of $36.7 \%$. Mariz et al. (2014) reported clinical success in $60.6 \%$ and radiographic in $54.5 \%$, while Daher et al. (2015) indicated a low clinical and radiographic success rate $(27.8 \%)$; differing widely with our findings.

Clinical success of CTZ paste on pulp treatment could be attributed to the fact that in the primary teeth, the presence of accessory ducts, porosity and permeability in the pulpal floor region indicates a probable connection

TABLE 3. Radiographic evaluation according to gender

\begin{tabular}{lcccccc}
\hline Gender & \multicolumn{5}{c}{ Radiographic evaluation } \\
\cline { 2 - 6 } & \multicolumn{5}{c}{ 6 months } & \multicolumn{3}{c}{12 months } \\
& Success & Failure & $\mathrm{p}^{*}$ & Success & Failure & $\mathrm{p}^{*}$ \\
\cline { 2 - 6 } & $\mathrm{n}(\%)$ & $\mathrm{n}(\%)$ & & $\mathrm{n}(\%)$ & $\mathrm{n}(\%)$ & \\
Female $(n=20)$ & $20(100)$ & $0(0)$ & & $19(95.0)$ & $1(5.0)$ & \\
Male $(n=23)$ & $22(95.7)$ & $1(4.3)$ & 0.534 & $21(91.3)$ & $2(8.7)$ & 0.553 \\
Total $(n=43)$ & $42(97.7)$ & $1(2.3)$ & & $40(93.0)$ & $3(7.0)$ & \\
\hline
\end{tabular}

* Chi Square Test 
between the pulp tissue and the periodontal tissues. The combination of antibacterial drugs can easily dissipate through these regions and induce a sterile area (Perez et al. 2012). Another important factor is to perform antisepsis in the area and placement of the paste that with its bacteriostatic action causes the bacterial colony can be reduced, since its fill, modifies the existing microflora, causing the number of microorganisms to decrease, modifying their pathogenicity (Perez et al. 2012; Reis et al. 2016). As a final point, pulpotomy with CTZ paste tratment, is a minimally invasive technique and does not required the uses of endodontic files in the root canals, allowing the finishing the procedure in a single appointment, enabling a better management of the pediatric patient's behavior, as it decreases the working time and prevents the premature loss of temporal molars with pulp involvement. However, more clinical and radiographic studies are required to evaluate their performance for longer periods of time.

\section{CONCLUSION}

CTZ paste (Chloramphenicol, Tetracycline, Zinc Oxide Eugenol) is an alternative in the treatment of pulpotomies in temporal molars, being a simple technique and easy to perform, it reduces work time in the dental procedures and has shown excellent clinical results, thanks to the antimicrobial effect of the components that constitute it, also promotes a stabilization on the process of root resorption and does not produce damage to the permanent tooth in development.

\section{REFERENCES}

Alolofi, H., El-Sayed, M. \& Taha, S. 2016. Clinical and radiographical evaluation of propolis and thymus vulgaris extracts compared with formocresol pulpotomy in human primary molars. BDJ OPEN 2: 1-6.

Azevedo, C., Barcelos, R. \& Primo, L. 2009. Variabilidade das técnicas de tratamento endodóntico em dentes decíduos para os procedimentos clínicos. Odontologia Clinico Cientifica 45(1): 37-43.

Bruno, G., Menezes, V., Bruno, J., Almeida, M.W. \& Viana, G.S.B. 2006. Hematological and biochemical evaluations of blood from dogs submitted to pulpotomies with an antibiotic sealer. Revista de Odontologia da UNESP 35(3): 125-133.

Daher, A., Alves, K., Rodrigues, C. \& Rezende, L. 2015. Ineffectiveness of antibiotic-based pulpotomy for primary molars: A survival analysis. Brazilian Research in Pediatric Dentistry and Integrated Clinic 15(1): 205-215.

Gonzalez, A., Ruiz, M., Pierdant, M., Garrocho, J. \& Pozos, A. 2016. Zinc oxide-eugenol pulpotomy in primary teeth: A 24-month follow-up. Journal of Clinical Pediatric Dentistry 40(2): 365-371.

Havale, R., Anegundi, R., Indushekar, K. \& Sudha, P. 2013. Clinical and radiographic evaluation of pulpotomies in primary molars with formocresol, glutaraldehyde and ferric sulphate. Oral Health and Dental Management 12(1): 24-31.

Hoelscher, A., Bahcall, J. \& Maki, J. 2006. In vitro evaluation of the antimicrobial effects of a root canal sealer-antibiotic combination against Enterococcus faecalis. Journal of Endodontics 32(2): 145-147.
Liu, H., Zhou, Q. \& Qin, M. 2011. Mineral trioxide aggregate calcium hydroxide for pulpotomy in primary molars. Chinese Journal of Dental Research 14(2): 121-125.

Luengo, J., Ramos, A., Hernandez, M., Diaz, C., Carlos, L. \& Toscano, I. 2016. Clinical and radiographic effectiveness of antibiotic paste CTZ in primary molars pulpotomy. Ramdomized Controlled Clinical Trial. International Journal of Odontostomatology 10(3): 425-431.

Mariz, P., Cavalcanti, R. \& Alvez, S. 2014. Clinical and radiographic monitoring of primary teeth submitted to pulp therapy with CTZ paste. Brazilian Research in Pediatric Dentistry and Integrated Clinic 14(3): 56-68.

Molina, N., Durán, D., Castañeda, E. \& Juárez, M. 2015. La caries y su relación con la higiene oral en preescolares mexicanos. Gaceta Medica de Mexico 151(4): 485-490.

Nanda, R., Koul, M., Srivastava, S., Upadhyay, V. \& Dwivedi, R. 2014. Clinical evaluation of $3 \mathrm{mix}$ and other mix in non-instrumental endodontic treatment of necrosed primary teeth. Journal of Oral Biology and Craniofacial Research 2(4): 114-119.

Nakornchai, S., Banditsing, P. \& Visetratana, N. 2010. Clinical evaluation of $3 \mathrm{mix}$ and vitapex as treatment options for pulpally involved primary molars. International Journal of Paediatric Dentistry 20: 214-221.

Oliveira, M. \& Costa, L. 2006. Desempenho clínico de pulpotomías com pasta CTZ en molares deciduos: Estudio retrospectivo. Robrac 15(40): 37-45.

Oliveira, T.M., Moretti, A.B., Sakai, V.T., Lourenço, N., Santos, C.F. \& Machado, M.A. 2013. Clinical, radiographic and histologic analysis of the effects of pulp capping materials used in pulpotomies of human primary teeth. European Archives of Paediatric Dentistry 14(2): 65-71.

Passos, I., Melo, J. \& Moreira, P. 2008. Utilizacao da pasta CTZ em demte decíduo com necrose pulpar - relato de caso. Odontologia Clinico Cientifica 7(1): 63-65.

Pérez, P., Curioca, S. \& Retana, R. 2012. Efectividad terapéutica de la pasta CTZ vs biomecánica convencional en pulpa necrótica de escolares de 4-8 años. Odontologia Actual 1(3): 28-36.

Perona, G. \& Mungi, S. 2014. Tratamiento endodóntico no instrumentado en dientes deciduos. Odontología Pediátrica 4(1): 53-64.

Pimenta, H.C., Borges, A.H., Bandeca, M.C., Neves, A.T., Fontes, R.G., da Silva, P.V. \& Aranha, A.M. 2015. Antimicrobial activity of filling materials used in primary teeth pulpotomy. Journal of International Oral Health 7(4): 54-57.

Pinky, C., Shashibhuhshan, K. \& Subbareddy, V. 2011. Endodontic treatment of primary teeth using two different combinations of antibacterial drugs: An in vivo study. Journal of Indian Society of Pedodontics and Preventive Dentistry 29(2): 121-127.

Reis, B.S., Barbosa, C.C.N., Soares, L.C., Brum, S.C., Barbosa, O.L.C.B. \& Marques, M.M. 2016. In vitro analysis of antimicrobial activity of CTZ binder used as material plug in deciduous teeth pulp. Revista Pró-UniverSUS 07(3): 39-42

Siegl, R., Lenzi, T., Politano, G., De Benedetto, M., Imparato, J. \& Pinheiro, S. 2015. Two endodontics techniques analysis in primary molars with fistula. Revista Gaucha de Odontologia 63(2): 187-194

Silva, C.C. \& Leach, E.B. 2010. Utilização do agregado trióxido mineral (MTA) em pulpotomias de molares temporários. Dentistry Clínica 70(1): 34-37. 
Simancas, M.A., Díaz,A.J. \& Luna, L.M. 2010. Mineral trioxide aggregate in primary teeth pulpotomy: A systematic literature review. Medicina Oral Patolologia Oral y Cirugia Bucal 15(6): 942-946.

Subramaniam, P. \& Gilhotra, K. 2011. Endoflas, zinc oxide eugenol and metapex as root canal filling materials in primary molars - A comparative clinical study. Journal of Clinical Pediatric Dentistry 35(4): 365-370.

Takushige, T., Cruz, E., Moral, M. \& Hoshino, E. 2008. Nonsurgical treatment of pulpitis, including those with history of spontaneous pain, using a combination of antibacterial drugs. Journal of LSTR Therapy 7: 1-5.

Takushige, T. \& Hoshino, E. 2009. Endodontic retreatment using 3Mix-MP without removal of previous root canal obturation. Journal of LSTR Therapy 8: 3-7.

Trairatvorakul, C. \& Detsomboonrat, P. 2012. Success rates of a mixture of ciprofloxacin, metronidazole, and minocycline antibiotics used in the non-instrumentation endodontic treatment of mandibular primary molars with carious pulpal involvement. International Journal of Paediatric Dentistry 22(3): 217-227.

Yildirim, C., Basak, F., Akgun, O., Guven, G. \& Altun, C. 2016. Clinical and radiographic evaluation of the effectiveness of formocresol, mineral trioxide aggregate, portland cement, and enamel matrix derivative in primary teeth pulpotomies: A two year follow-up. Journal of Clinical Pediatric Dentistry 40(1): 14-20.

World Medical Association. 2013. Declaration of Helsinki ethical principles for medical research involving human subjects. Journal of the American Medical Association 10(20): 21912194.
Jesús Luengo Fereira*, Heraclio Reyes Rivas \& Luz Elena Carlos Medrano

Pediatric Dentistry Postgraduate Program

School of Dentistry

Zacatecas Autonomous University

México

Iovanna Toscano \& Minerva Anaya Alvarez

Medical Surgeon Dentist Program

School of Dentistry

Zacatecas Autonomous University

México

*Corresponding author; email: jluengo@uaz.edu.mx

Received: 21 September 2017

Accepted: 29 December 2017 